\title{
SOME ASPECTS OF TRUST IN SERVICE ACTIVITIES
}

\section{WOJCIECH DOWNAR}

University of Szczecin, Faculty of Management and Economics of Services, POLAND

e-mail: wojciech.downar@wzieu.pl

\begin{tabular}{l|l} 
RECEIVED & 6 November 2018 \\
ACCEPTED & 3 December 2018 \\
JEL & \\
CLASSIFICATION & L29, L84, M12
\end{tabular}

KEYWORDS services, management, trust, organisational behaviour

ABSTRACT The issue of trust is rarely addressed in the context of service activities. The specificity of services, their diversity and the way they are produced make trust an important determinant of effective and efficient services provision. The simultaneity of production and consumption as well as the lack of transfer of ownership of the service in the process of its production result in the asymmetry of information between the customer and the service provider. Trust based on the perception of integrity and goodwill of the service provider is necessary. Relations between the customer and the employee of the service provider are based on the customer's trust to the individual skills and competencies of the employee. The features of the service delivery process determine the work design of the service provider based on empowerment replacing direct control with trust-based relationships. Also the type of service, in particular the intensity of contact with the customer and the degree of customisation, determine the strength of trust in relations with customer.

\section{Introduction}

Trust is an interdisciplinary concept that in recent decades has found its permanent place in the theory and practice. The phenomenon of trust is described and interpreted in such disciplines as sociology, social psychology, philosophy and law (Perri, Goodwin, Peck, Freeman, 2006, p. 84). Trust is also widely discussed in economics, business and management (Grudzewski, Hejduk, Sankowska, Wańtuchowicz, 2007, p. 33). Trust is extensively 
discussed in a general context, without distinguishing between industrial and service activities. Although there is no doubt about the role of trust in service activities the existing literature only marginally addresses this topic. One can say that the issues of trust in service activities are less examined than in industry, despite the fact that its role is equally important (or even greater). The paper takes a review of the relevant literature and is an attempt to fill the gap in the literature by extending existing theory on trust in the context of service activities. The research objective of the paper is to explore the issue of trust in services providing, taking into account the specific characteristics of services. The very essence of services and theirs heterogeneity and complexity and the specificity of the service delivery process require understanding of the concept of trust. The paper adapts the concept of the service triangle as a framework for recognition and understanding of trust in the three dyads identified in the triangle. Conceptualization of the role of trust in services providing is based on a limited number of articles. However, it can serve as a starting point for the development of this issue and as a basis for future studies and research.

\section{The concept of trust in service activities}

The subject of trust in business activities is discussed in literature in many contexts: trust in project management (Gapiński, 2017, p. 4), trust in virtual organisation (Grudzewski at al., 2007, p. 191), influence of trust on outcomes (Kim, Wang, Chen, 2018, p. 947), trust in leader - employee relation (Karlsen, Græe, Massaoud, 2008, p. 9).

Trust can be defined as a belief by one party in a relationship that the other party will not act against his or her interests, where this belief is held without undue doubt or suspicion and in the absence of detailed information about the actions of the other party (Tomkins, 2001, p. 165). Trust can also be defined as willingness of a party to be vulnerable to the actions of another party based on the expectation that the other party will perform a particular action important to the trustor, irrespective of the ability to monitor or control the other party (Burke, Sims, Lazzara, Salas, 2007, p. 608). Trust is inseparable from risk. Therefore, it can be concluded that the relationship that exists between the parties occurs in an environment that can be described as a risky exchange situation. In this context trust can be defined in terms of one's assessment of other's goodwill and reliability in a risky exchange situation (Ring, de Ven, 1992, p. 488). A trust is always unidirectional and connects two entities: trustor (services receiver, customer) and trustee (services provider) (Figure 1).

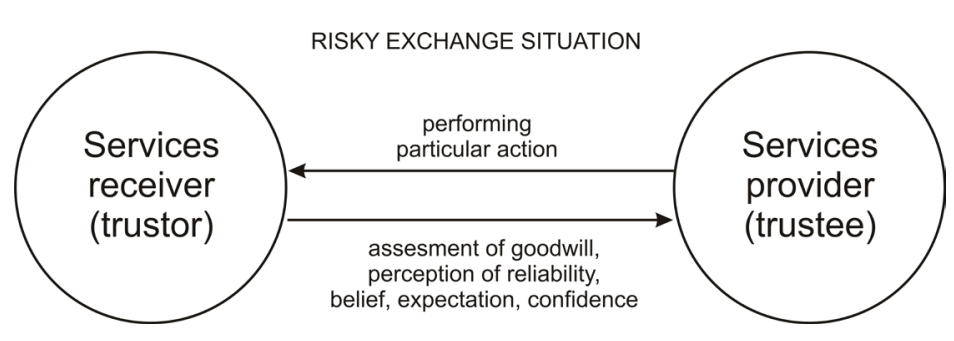

Figure 1. Definition of trust in services providing

Source: own elaboration based on Tomkins (2001), p. 164.

Bhattacharya at al. (Bhattacharya, Devinney, Pillutla, 1998, p. 461) distinguish six elements of trust:

- trust contains an element of uncertainty and risk, 
- trust reflects an aspect of predictability - this is the predictions of someone's behaviour,

- any definition of trust must account for the strength and importance of trust - it can occur with varying degrees depending on the circumstances,

- trust exists in an environment of mutuality,

- trust in its essence is a positive concept. Trust is "good". When we speak of trust, we are making a statement about the likelihood of positive - not negative - outcomes.

Trust is seen as a phenomenon pertaining to relations between individuals. Considering the services providing, to determine the relationship parties one can adopt the concept of a service triangle. The service triangle is a dynamic model in which three interlinked entities (customer, employee and firm) combine to create three dyads: customer - employee (CE), customer - firm (CF), and internal dyad employee - firm (EF) that work together to deliver services (Anderson, Smith, 2017, p. 237) (Figure 2). Trust can also exist at a variety levels within the firm (the service provider), i.e. at the team level (between team members), leadership level (between the team member and the leader), the organisational level (between employees and the organisation) (Burke at al., 2007, p. 610). Trust can also be considered at the inter-organisational level but as Nielsen (2004, p. 241) noted, there is no clear idea how individual trust translates into organisational one.

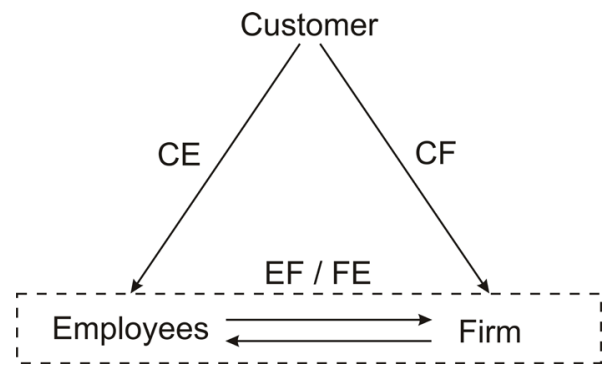

Figure 2. Trust relations in the services triangle

Source: own elaboration based on Anderson and Smith (2017), p. 238.

Each dyad within the service triangle can be considered from the point of view of trust. In the CF relation, trust is determined by the perception of reliability and goodwill by the customer, because the provision of services is based on a risk situation unfavourable to the customer, consisting in the lack of transfer of ownership and the service specification in the form of postulates.

In the CE relation trust is determined by the perception of individual characteristics and behaviour of the person with whom the customer has direct contact. The service provider is not unnamed, and the customer sees the 'manufacturer' of the service, i.e. an employee with whom he or she has direct contact.

The CE relationship influences the way work is organised inside the firm. The work design is based on the specific relationship between the firm and the employee who provides services directly. The work design is characterised by a high degree of independence and discretion of the employee. Mutual trust is required in relations of $\mathrm{FE}$ (to use empowerment as a substitute of control) and of $\mathrm{EF}$ (to motivate and encourage reasonable risk taking). 


\section{Impoptance of trust in service activities}

Trust is of great importance in business operations, including services providing. Trust enables cooperative behaviour (Rousseau, Sitkin, Burt, Camerer, 1998, p. 397), promotes adaptive organisational forms, reduces damaging conflicts and transaction costs, and promotes more effective responses to crisis. Trust can be a substitute for more formal control methods (Karlsen at al., 2008, p.9). Building trust between two organisations encourages them to assume joint risks and to engage in recurrent business transactions (Ring, Van de Ven, 1992, p. 488).

Table 1. Importance of trust

\begin{tabular}{ll}
\multicolumn{1}{c}{ Author } & \multicolumn{1}{c}{ Trust: } \\
\hline R. Oliver (1997), p. 41 & enables 'simplification mechanism' \\
\hline P.S. Ring, A.H. Van de Ven (1994), p. 99 & enables condition, which facilitates the formation of networks \\
\hline D. Rousseau et al. (1998), p. 397 & - enables cooperative behaviour, \\
& - promotes adaptive organisational forms, \\
& - reduces damaging conflicts, \\
& - reduces transaction costs, \\
& - promotes more effective responses to crisis \\
\hline A.S. Humphries, R.D. Wilding (2004), p. 1112 & provides substitute for more formal control methods \\
\hline A.W. Laing, P.C.S. Lian (2005), p. 115 & reduces the complexity, the risk and uncertainties of a decision \\
\hline W.M. Grudzewski at al., 2007, p. 31 & - enables cooperation, \\
& - facilitates developing trust capital, \\
& - determines decision making, \\
& - creates openness and clarity in relations, \\
& - facilitates communication \\
\hline U. Singh, K.B.L. Srivastava (2016), p.597 & encourages organisational citizenship behaviour (OCB) \\
\hline
\end{tabular}

Source: own elaboration.

Trust can reduce the complexity and hence the risk and uncertainties of a decision by acting as what $\mathrm{R}$. Oliver (1997, p. 41) described as a 'simplification mechanism'. The benefits of trust can be summarised in three areas:

- the change or modification of the behaviour of entities (trust increases motivation, reduces conflicts, improves job satisfaction, and encourages cooperative behaviour, e.g. altruism, courtesy, civil virtue),

- direct economic benefits (trust as a substitute of formal control, reduction of transaction costs) and individual performance,

- functioning of the organisational structure (trust promotes adaptive organisational forms, reduces the complexity of decision making, facilitates communication, encourages information sharing and formation of networks, improves acceptance of goals and decisions).

The importance of trust in service activities results from:

(a) the very essence of the service,

(b)the specific form of work organisation during the provision of services and

(c) the high degree of interdependence between the various entities necessary to produce the service (especially in the case of knowledge intensive services).

(a) The exchange of value during the delivery of services is based on the flow of a clearly defined value (from the customer to the service provider) and on the other hand the service provider promises to deliver the service in a certain standard. B. Hollins, S. Shinkins (2006, p. 10) stated that service delivery process is 'based on promise'. 
The process of service providing is based on the asymmetry of exchange in which the customer provides real value (e.g. pays for the service) and the service provider promises to deliver value. In addition, the simultaneity of consumption and production means that the purchase of services does not involve the transfer of ownership. As Ph. Kotler, G. Armstrong (2010, p. 248) noted the service is any activity or benefit that one party can give to another that is essentially intangible and does not result in the ownership of anything. Providing the 'based on promise' service without the transfer of ownership means that trust is of crucial importance. Otherwise the service provider would not be able to provide the service at all.

(b) The specificity of services, in particular the simultaneity of production and consumption, is one of the major reason to allow front-line employees a high degree of discretion when dealing with customers. In the process of service provision there is no time for consultation with managers thus employees are forced to make decisions by themselves being managers on their own. Accordingly, high degree of delegation and autonomy is required. This evokes the need to reduce direct control and replace it with trust in the process of empowering employees.

(c) Heterogenity and complexity of services providing often result in necessity to acquire knowledge from other entities (especially in knowledge intensive services). Existing dyadic relationships between parties are transformed into complex network dependencies. The number of stakeholders involved in the process of services providing can dramatically increase the complexity of the process. When a large number of parties, their interests, reasons and pressures cannot be directly controlled trust then grows into the role of 'simplification mechanism'.

\section{The impact of service category on trust}

Trust is situation specific. Different types of services require different levels of trust, and the type of service determines the level of trust. There are many criteria for the division of services in the literature: degree of labour intensity, complexity, degree of consumer provider interaction, degree of value co-creation intensity, degree of heterogeneity ( $\mathrm{Ng}$, Russell-Bennett, Dagger, 2007, p. 472).

These criteria are often related to each other, creating multidimensional classifications. Criteria for classifying services that are important from the point of view of trust are:

- contact with the customer,

- degree of customisation of the service.

R.B. Chase (1981, p. 700) classifies services according to the extent of customer contact required in service delivery. In high contact services customers exert more influence on timing of demand and services feature. Although high contact services allow detailed personalisation of the services and allow employees more discretion but are harder to control. P.K. Mills and N. Margulies (1980, p. 262) give attention to personal interface between the customer and service organisation. According to authors there are three types of services: maintenance-interactive, task-interactive and personal-interactive.

Maintenance-interactive services concentrate on routine and standardized contacts between employee and the customer. Contact is usually short, the flow of information limited and employee may serve large number of customers. In this type of services the required degree of trust is low. The relationship is largely objectivised, thanks to existing standards and procedures. Asymmetry of information that causes risk in the process of providing this type of services is relatively small.

Task-interactive services are oriented toward particular task. Customers are precise about what they need but they do not know how to accomplish it. This type of service requires a high degree of trust. Task-interactive services 
require specialised expert knowledge to solve the problem. The relationship is intense but information asymmetry exist, and the customer is not able to deliver much critical professional information. Customers are unaware the nature of the problem and methods and techniques used by the professional service provider. Trust has an even more significant role to play in the context of professional services, as the professionals responsible for the delivery of such services are perceived to have a particular capacity to generate and maintain trust in market exchange as a result of their primary professional commitment being to the client (Laing, Lian, 2005, p. 115).

Personal-interactive services imply the most complex type of interaction. A customer seeks help from an organisation providing counselling, but may be unaware the extent of the problem. Based on information from the customer (often confidential or even intimate), service provider engage in the process of defining problem and ways of solving. For these services, the strength of trust is of crucial importance. It is caused not only by information asymmetry, but also a certain degree of openness and willingness to cooperate and provide information that will allow to identify the problem is required. An example of such services are some medical services, e.g. psychotherapist. In this case, trust is necessary because the client must be sure that such information will be kept confidential and will not be used against.

\section{Conclusions}

The role of trust in the delivery of services must be considered in the context of their specific characteristics. From this perspective the simultaneity of production and consumption results in the asymmetry of information between parties and, consequently, the occurrence of a risky exchange situation. Trust is assigned to relationships between individuals, but in service activities, it should also be extended on organisational as well as interorganisational levels. The basic trust relationship is the relationship between the customer and the service provider as well as the employee of service provider. Intra-organisational trust relationships make it possible to organise work that allows a high degree of empowerment of the employees. Trust is not a homogeneous phenomenon in the process of providing services. One of the key determinants affecting the strength and significance of trust is the complexity of the service provided, consequently the frequency of contact with the customer and the degree of customisation of the service.

\section{References}

Anderson, S., Smith, J. (2017). An empirical examination of the services triangle. Journal of Services Marketing, 31 (3), 236-246.

Bhattacharya, R., Devinney, T.M., Pillutla, M.M. (1998). A Formal Model of Trust Based on Oucomes. Academy of Management Review, $23(3), 459-472$.

Burke, C.S., Sims, D.E, Lazzara, E.H., Salas, E. (2007). Trust in leadership: A multi-level review and integration. The Leadership Quarterly, 18 (6), 606-632.

Chase, R.B. (1981). The customer contact approach to services: Theoretical bases and practical extensions. Operations Research, 29 (4), 698-706.

Gapiński, A.J. (2017). Trust in Project Management. The Journal of Management and Engineering Integration, 10 (2), 1-11.

Grudzewski, W.M., Hejduk, I.K., Sankowska, A., Wańtuchowicz, M. (2007). Zarządzanie zaufaniem w organizacjach wirtualnych. Warszawa: Difin.

Hollins, B., Shinkins, S. (2006). Managing Service Operations. Design and Implementation. Sage Publications.

Humphries, A.S., Wilding, R.D. (2004). Long term collaborative business relationships: the impact of trust and C3 behavior. Journal of Marketing Management, 20 (9), 1107-1122. 
Karlsen, J.T., Græe, K., Massaoud, M.J. (2008). Building trust in project-stakeholder relationships, Baltic Journal of Management, 3 (1), 7-22.

Kotler, Ph., Armstrong, G. (2010). Principles of Marketing. Pearson.

Laing, A.W., Lian, P.C.S. (2005). Inter-organisational relationship in professional services: towards a typology of service relationships. The Journal of Services Marketing, 19 (2), 114-127.

Mills, P.K., Margulies, N. (1980). Towards a core typology of service organizations. Academy of Management Review, 5 (2), $255-265$.

$\mathrm{Ng}$, S., Russell-Bennett, R., Dagger T. (2007). A typology of mass services: the role of service delivery and consumption purpose in classifying service experiences. Journal of Services Marketing, 21 (7), 471-480.

Nielsen, B.B. (2004). The Role of Trust in Collaborative Relationships: A Multi-Dimensional Approach, Management, 7 (3), $239-256$.

Oliver, R. (1997). Satisfaction: A Behavioral Perspective on the Consumer. MacGraw-Hill.

Perri, P., Goodwin, N., Peck, E., Freeman, T. (2006). Managing Networks of Twenty-First Century Organisations. Palgrave Macmillan.

Ring, P.S., Van de Ven, A.H. (1992). Structuring Cooperative Relationships between Organizations. Strategic Management Journal, $13(7), 483-498$.

Ring, P.S., Van de Ven, A.H. (1994). Developmental Process of Cooperative Inter-organizational Relationships, Academy of Management Review, 19 (1), 90-118.

Rousseau, D., Sitkin, S.B., Burt, R.S., Camerer, C. (1998). Not so different after all: a cross-discipline view of trust. Academy Management Review, 23 (3), 393-404.

Singh, U., Srivastava, K.B.L. (2016). Organizational Trust and Organizational Citizenship Behaviour. Global Business Review, 17 (3), 594-609.

Tae-Yeol Kim, Jie Wang, Junsong Chen (2018). Mutual Trust Between Leader and Subordinate and Employee Outcomes. Journal of Business Ethics, 149 (4), 945-958.

Tomkins, C. (2001). Interdependencies, trust and information in relationships, alliances and networks. Accounting, Organizations and Society, 26 (2), 161-191.

Cite this anticle aS: Downar, W. (2018). Some aspects of trust in service activities. European Journal of Service Management, 4 (28/1), 79-85. DOI: 10.18276/ejsm.2018.28/1-10. 